\title{
Attitudes towards smart technologies among older people and their informal carers in Slovenia
}

\author{
Simona Hvalič-Touzery, Vesna Dolničar \\ University of Ljubljana, Faculty of Social Sciences, Centre for Social Informatics \\ Simona.Hvalic-Touzery@fdv.uni-lj.si
}

\section{Abstract}

Introduction: Despite the growing body of evidence of smart solutions' positive outcomes on older people and their informal carers, the use of these solutions is still low, even more so in Slovenia. Moreover, in recent years, mostly single smart solutions have been developed, covering only a small range of applications. The international project i-evAALution evaluated the acceptance and the impact of the bundle of several single solutions (emergency watch, tablet and smart home devices) on community-dwelling older people and their informal carers. We present the preliminary results of only one segment of the whole study focusing on the results of a baseline questionnaire conducted in Slovenia. Methods: The randomised control trial was conducted in 2019-2O21 in the Central Slovenia region. A total of 55 dyads, including older care recipients (PE) and their primary informal carers (SE), were recruited and completed the baseline questionnaire. Care recipients were on average 78.6 years old $(\mathrm{SD}=7.79)$ and $43.6 \%$ had fallen in the past year. Carers were on average 52.8 years old $(\mathrm{SD}=11.58)$. On average, they provided 5.8 hours of care per week $(\mathrm{SD}=10.41)$ and had been doing so for an average of 6.6 years $(\mathrm{SD}=7.69)$. The majority $(71 \%)$ of carers were the children of the care recipient. Participants completed questionnaires at three or four measurement time points: at baseline (before randomisation to test or control group), post-installation (test group only), after 4-5 months (both groups), and after 12 months (control group only). Data were processed using the statistical package SPSS 20.0. Results: We observed a significant difference in technology competence between care recipients and carers $(\mathrm{MPE}=2.63, \mathrm{MSE}=2.12, \mathrm{p}=0.000)$ and the interest in technology $(\mathrm{MPE}=3.12, \mathrm{MSE}=3.70, \mathrm{p}=0.004)$. In addition, the most important features of a tested i-evAALution bundle recognised by both carers and care recipients were safety (MPE $=$ 4.32, $\mathrm{MSE}=4.46)$, emergency services $(\mathrm{MPE}=4.17, \mathrm{MSE}=4.41)$ and 
technical services $(\mathrm{MPE}=4.17, \mathrm{MSE}=4.36)$. The least important feature was leisure activities $(\mathrm{MPE}=1.98, \mathrm{MSE}=2.35)$. On average, it was more important to informal carers that care recipients could use the tablet to call family members or friends $(\mathrm{MSE}=3.27, \mathrm{p}<.05)$ than it was to care recipients $(\mathrm{MPE}=2.65)$. It was also more important for carers that the tablet reminded care recipients to take their medications $(\mathrm{MSE}=3.67)$ than for care recipients $(\mathrm{MPE}=2.94, \mathrm{p}<.05)$. Discussion and conclusions: This study contributes to a limited empirical evidence on the acceptance and attitudes of older people and their informal carers in Slovenia towards smart solutions in health and social care. Understanding their perceptions of technology and needs can also help the developers of such solutions, as well as the providers in the market, and support better deployment of such smart solutions in health and social care.

Keywords: assistive technologies, technology acceptance, technology attitudes, randomised control trial

\section{Introduction}

"Ageing in place", i.e. enabling people to live in their homes and communities for as long as possible, rather than in an institution, is the prevailing concept in current ageing policy (Wiles et al., 2012). However, in most EU countries, this concept is not sufficiently supported by social policies (Kröger et al., 2018) and pressures on informal carers are high and increasing (Spasova et al., 2018). Despite differences in long-term care (LTC) systems, informal care accounts for the majority of care hours in all European countries which is even more pronounced with the rising number of people in need of care and the lack of accessible formal LTC services and personnel (Kröger et al., 2019; Spasova et al., 2018). Despite these trends, in some countries, including Slovenia with its fragmented LTC system, the needs of informal carers are poorly met (Hlebec et al., 2021), although Slovenian Active Ageing Strategy (Bednaš and Kajzer, 2018) recognises the importance of improving support for informal carers and their integration into the LTC system.

According to Slovenian Public Opinion Survey (SJM) 2021, $30.6 \%$ of the population (aged 18 and over) provide at least 4 hours of unpaid informal care per week to a person aged 65 or over (Hafner-Fink et al., 2021; Dolničar et al., 2021). This refers to the provision of personal care activities (ADL) and/or activities related to independent living (IADL) and/or emotional support. The proportion of carers increases with age while they are still of working age (Tur-Sinai et al., 2020; Zigante, 2018), as also found in the Slovenian survey using an Online Access Panel 2021 (Dolničar et al., 2021). The proportion of informal carers of older people reported in these two Slovenian studies is significantly higher than in some other studies (Eurofound, 2017; Eurostat, 2019; Tur-Sinai et al., 2020). In 2013, $75.54 \%$ of Slovenian people aged 65 years or older, who received some type of care at home, received only informal care, $6.66 \%$ received only formal care, and $17.79 \%$ received a combination of the two (Hlebec et al., 
2016). As Dolničar et al. (2021) found, pressure on informal carers increased during the Covid 19 pandemic.

One way to address some of these challenges is to harness the potential of new technologies to support LTC and informal carers (Eurocarers, 2019), which is increasingly being proposed in European policy (Eurocarers, 2018, 2019; European Ageing Network, 2019; European Commission, 2021). A recent European Commission report calls for deployment of different ICT solutions for informal carers and older people and for addressing the lack of digital skills and mistrust of new technologies (Social Protection Committee (SPC) \& European Commission (DG EMPL), 2021; Zigante, 2021).

Despite evidence of the positive impact of these new technologies on older people (e.g., improved quality of life, increased safety, independence, reduced social isolation) (Khosravi et al., 2016; Siegel and Dorner, 2017)) and their informal carers (e.g. increased peace of mind and reassurance) (Andersson et al., 2017, Smole-Orehek et al., 2019, D'Onofrio et al., 2017), the prevalence of their use is still low, which is particularly pronounced in Slovenia.

The aim of this paper is to assess:

- which telecare functionalities are the most important for community-dwelling care receivers aged 65 and over (PE) and their informal carers (SE);

- $\quad$ technology competence among PEs and SEs and differences between them.

\section{Methods}

The present study was conducted as part of the i-evAALution project and is part of the randomised control trial (RCT), which ran from 2019 to 2021 in Slovenia, Austria, Italy and the Netherlands. For this paper, only the selected baseline section of RCT (i. e. before randomisation to test or control group and before installation of the bundle of AAL solutions), which relates to the Slovenian pilot site, is presented and discussed. The study has received ethical approval from the University Innsbruck Ethical Review Board (28/2019). Descriptive statistics and bivariate analyses were calculated.

\section{Instruments}

The Technology Commitment Scale (TC scale) (Neyer et al., 2012) was found to be moderately reliable, with a Chronbach Alpha of 0.662 for PE and 0.620 for SE. Other questions presented in this paper were developed by the project consortium. 


\section{Sample}

The Slovenian sample consisted of 55 dyads from PE and their SE. Both PEs (74.5 $\%$ ) and SEs (63.4 \%) were predominantly female. PEs were on average 78.4 years old and a higher proportion (67.3\%) lived in a single-person household. All but one SE owned a smartphone and a computer, while $67.3 \%$ of PEs owned a computer and 58.2\% owned a smartphone. A large proportion of PEs (70.4 \%) considered themselves independent, but $43.6 \%$ had experienced a fall in the past year. SEs were on average 52.8 years old $(S D=11.58)$. SEs in the sample were well educated, with nearly three-quarters having a university degree or more. Those who cared for PE did so for an average of 5.8 hours per week $(\mathrm{SD}=10.41)$ and an average of 6.6 years $(\mathrm{SD}=7.69)$. The majority $(71 \%)$ were children of SEs, followed by partners $(14.5 \%)$. Just over a quarter of SEs $(27.3 \%)$ lived in the same building as PEs and another fifth lived within walking distance. The remaining half of SEs were 15 minutes or more drive from PEs, and half of them were up to 30 minutes away.

Results

Importance of telecare functionalities

Table 1. Importance of eight main areas of telecare functionalities

\begin{tabular}{lcccc}
\multirow{2}{*}{\multicolumn{1}{c}{ Telecare functionalities }} & \multicolumn{2}{c}{$P E$} & \multicolumn{2}{c}{$S E$} \\
\cline { 2 - 5 } & $M$ & $S D$ & $M$ & $S D$ \\
\hline Safety and security & 4.32 & 0.687 & 4.46 & 0.482 \\
\hline Technology-related services & 4.17 & 1.052 & 4.36 & 0.841 \\
\hline Emergency services & 4.17 & 1.065 & 4.41 & 0.885 \\
\hline Services in case of need & 4.04 & 1.095 & 4.14 & 1.073 \\
\hline Health and care & 3.33 & 1.343 & 3.66 & 1.107 \\
\hline Living environment & 2.65 & 1.262 & 2.87 & 1.25 \\
\hline Information and communication & 2.57 & 1.202 & 2.98 & 1.102 \\
\hline Leisure activities & 1.98 & 1.201 & 2.35 & 1.377 \\
\hline
\end{tabular}

Legend: $M=$ Mean; $S D=$ Standard deviation

Note: Perceived importance of TC functionalities was measured on a 5-point scale:

1-not important, 2-slightly important, 3-moderately important, 4-significant, 5-significantly important.

All but three participants in the study had no experience with telecare services. However, participants were introduced to telecare services during the project's introductory session. After the introduction, participants rated a range of functionalities of telecare services in eight main areas (safety, technology-related services, emergency services, services in case of need, health and care, living environment, information and communication, leisure) according to how important they perceived them to be. When observing eight main areas of telecare functionalities, we found no statistically significant differences between the responses of PEs and SEs. Both, PEs and SEs, identified provision of safety 
$(\mathrm{MPE}=4.32, \mathrm{MSE}=4.46)$, provision of emergency services $(\mathrm{MPE}=4.17, \mathrm{MSE}$ = 4.41), and technology-related services (e.g., installation, maintenance) (MPE $=4.17, \mathrm{MSE}=4.36)$ as the most important functionalities of telecare services. The least important functionality was leisure activity $(\mathrm{MPE}=1.98, \mathrm{MSE}=2.35)$ (Table 1).

Beside studying main areas of telecare functionalities, we also investigated the importance of specific functionalities, which were measured with a battery of 29 indicators within eight main areas of functionalities. We found a statistically significant difference in responses between PEs and their SEs on only two indicators. On average, it was more important to the SEs that PE could use the tablet to call family members or friends $(\mathrm{MSE}=3.27, \mathrm{SD}=0.184$ ) than it was to PEs $(\mathrm{MPE}=2.65, \mathrm{SD}=0.193, \mathrm{t}(107)=-2.342, \mathrm{p}<.05)$. It was also more important for the SEs that $\mathrm{PE}$ has a medication reminder $(\mathrm{MSE}=3.67, \mathrm{SD}=0.173)$ than for $\mathrm{PE}(\mathrm{MPE}=2.94, \mathrm{SD}=0.213, \mathrm{t}(105)=-2.640, \mathrm{p}<.05)$.

\section{Technology competence}

We found a statistically significant difference in the technology competence of PEs and SEs $(\mathrm{MPE}=2.61, \mathrm{MSE}=\mathbf{2 . 1 2}, \mathrm{p}=0.000)^{1}$ as well as in their interest in technology $(\mathrm{MPE}=3.12, \mathrm{MSE}=3.70, \mathrm{p}=0.004)$. Both PEs and SEs showed interest in technological developments, with the proportion of SEs who fully or largely agreed with this statement $(78.2 \%)$ being significantly higher than the proportion of PEs (47.3\%). The data also shows that more than one-third of PEs find dealing with new technologies challenging and difficult. In addition, more than half of SEs agreed that dealing with technological innovations is usually overwhelming for them.

We were interested also in participants' self-perceived ability to use new technologies compared to the general technology skills of their peers. $85.5 \%$ of SEs and half (50.9 \%) of PEs rated them as very good or good. A significant proportion (30.9 \%) of PEs rated their ability to use new technologies as average and $\mathbf{1 8 . 2} \%$ rated their ability as poor or that they were complete novices. No correlation was found between PEs' ability to use new technologies and their assessment of the importance of individual telecare functionalities ( $p>0.05)$.

\section{Discussion}

A substantial proportion of the PEs in our study were still independent, although slightly less than half had a history of falls. However, regardless of health status, PEs and SEs both identified the provision of safety and emergency services as the most important functionalities of telecare services. These functionalities of telecare services provide security and rapid response in emergency situations, which are perceived benefits that may lead to the adoption of such

$1 \quad$ Technology competence and technology interest were each measured with 4 items as part of the TC scale. Technology competence was measured with negative-worded items; higher average score indicates lower competence. 
technologies among PEs and SEs, which has been discussed in several studies (Dolničar et al., 2017; Epstein et al., 2016; Hvalič Touzery et al., 2021; Jaschinski et al., 2021; Jaschinski and Ben Allouch, 2019; Mahoney, 2011; Olsson et al., 2012; Verloo et al., 2020; Williamson et al., 2017).

With regard to the second objective of the present study, it was found that although both participants have high ownership of everyday technologies (e.g., computers, smartphones), PEs have lower technology competence and interest in technology than SEs. This is also reflected in a low percentage of PEs and SEs who rated their ability to use new technologies as poor. Present study also found that some SEs find dealing with technological innovations overwhelming and PEs find dealing with new technologies challenging and difficult. Therefore, the importance of external support from telecare providers when using a telecare solution (e.g. installation, maintenance, technical support) is paramount and this was also expressed by the PEs and SEs in our study who ranked this support among the top three features of telecare services. These findings confirm the need to support both PEs and SEs in using telecare solutions. As evidenced by many studies, successful use of telecare solutions requires both initial training and continuous technical support during use, characterised by high quality, responsiveness and user - friendliness (Epstein et al., 2016; Gibson et al., 2019; Jaschinski and Ben Allouch, 2019; Sriram et al., 2019; Verloo et al., 2020; White et al., 2020; Williamson et al., 2017).

A recent study by Steils et al. (2021) concludes that informal carers are often an important source of help for older people in using assistive technologies. A prerequisite for this type of assistance is sufficient technology competence and openness to new technologies. In our sample of SEs, we found high levels of technology competence and interest in new technologies, whereas this was lower in PEs. Therefore, we can conclude that it is important to involve family members of older individuals in technology adoption, as reported in previous studies (Jaschinski et al., 2021; Luijkx et al., 2015).

Finally, some difference was found between PEs and SEs in terms of their interest in the new technologies, with SEs expressing greater interest, which is consistent with the findings of other studies. As the use of telecare is often a joint decision between PE and SE (Cook et al., 2018; Jaschinski et al., 2021; Jaschinski and Ben Allouch, 2019; Luijkx et al., 2015), it is even more important that SEs support new technologies.

\section{Study limitations}

The study design affected the sample size. It is somewhat small, but the sample has the advantage of including dyads. We invited all interested parties to participate. This resulted in an unbalanced distribution of participants in the sample by educational background. In fact, we have a high proportion of highly educated SEs in the sample. Aditionally it is possible that individuals with greater 
interest in the new technology have decided to participate in the study so there can be a bias in the data on their technology competence and interest.

\section{Conclusions}

Our study confirms the potential of telecare services to address challenges related to LTC. There are many challenges that Slovenian society needs to address in order to realize the full potential of telecare solutions. As can also be seen in our sample, people are not familiar with telecare solutions and do not use them. However, as our study also shows, they recognize their potential and express interest in using them. Therefore, these technologies should be made available to informal carers and older people. In addition, public authorities need to recognize the role and care needs of informal carers and thus promote a policy framework for the creation of telecare services for informal carers and beyond. At the same time, familiarity with and acceptance of these technologies needs to be promoted not only among the general population but also among social and health care professionals.

\section{Acknowledgement}

The study was carried out in the framework of the project i-evAALution, supported by AAL JP and projects Factors influencing the intention to use smart technology-enabled care services among family caregivers of older people in the context of telecare and Programme Internet research, financially supported by the Slovenian Research Agency (J5-1785, P5-0399).

\section{References}

BEDNAŠ, M., and KAJZER, A. (Eds.), 2018. Active Ageing Strategy. Ljubljana: Institute of Macroeconomic Analysis and Development of the Republic of Slovenia; Ministry of Labour, Family, Social Affairs and Equal Opportunities [online]. [viewed 5 January 2020]. Available from http://www. umar.gov.si/fileadmin/user_upload/publikacije/kratke_analize/Strategija_dolgozive_druzbe/UMAR_SDD_ang.pdf

DOLNIČAR, V., PETROVČIČ, A., ŠETINC, M., KOŠIR, I., and KAVČIČ, M., 2017. Understanding Acceptance Factors for Using e-care Systems and Devices: Insights from a Mixed-Method Intervention Study in Slovenia. In J. Zhou and G. Salvendy (Eds.), Human Aspects of IT for the Aged Population. Applications, Services and Contexts (pp. 362-377). Cham: Springer International Publishing.

DOLNIČAR, V., TRKMAN, M., BERZELAK, J., BARTOL, J., and HVALIČ TOUZERY, S., 2021. Pomoč starejšim osebam s strani družinskih članov ali sorodnikov in njihov odnos do novih tehnologij: Sumarni pregled frekvenčnih porazdelitev in opisnih statistik zbranih podatkov (raziskovalno poročilo na ARRS projektu J5-1785). Fakulteta za družbene vede. Forthcoming publication. 
EPSTEIN, I., ALIGATO, A., KRIMMEL, T., and MIHAILIDIS, A., 2016. Older Adults' and Caregivers' Perspectives on In-Home Monitoring Technology. Journal of Gerontological Nursing, vol. 42, no. 6, pp. 43-50.

HAFNER-FINK, M., BRODER, Ž., DOUŠAK, M., FALLE ZORMAN, R., GERDINA, O., JAGODIC, A., KECMAN, I., KURDIJA, S., MIHELJAK, V., PAJNIK, M. et al., 2021. Slovensko javno mnenje 2021/1 - Poročilo o izvedbi raziskave in sumarni pregled rezultatov. Center za raziskovanje javnega mnenja in množičnih komunikacij, Univerza v Ljubljani, Fakulteta za družbene vede.

HLEBEC, V., RAKAR, T., DOLNIČAR, V., PETROVČIČ, A., and FILIPOVIČ HRAST, M., 2021. Intergenerational solidarity in Slovenia: Key issues. In I. Albert (Ed.), Families and family values in society and culture, (Perspectives on human development). Charlotte: Information Age, pp. 359380.

HLEBEC, V., SRAKAR, A., and MAJCEN, B., 2016. Determinants of Unmet Needs Among Slovenian Old Population. Slovenian Journal of Public Health, vol. 55, no. 1, pp. 78-85.

HVALIČ TOUZERY, S., SMOLE-OREHEK, K., and DOLNIČAR, V., 2021. Family carers' perspective on how older people perceive telecare. Presented at the Places, spaces and cultures of ageing - European Sociological Association's Research Network on Ageing in Europe Midterm conference, Jyväskylä. Retrieved from University.

JASCHINSKI, C., ALLOUCH, S. B., PETERS, O., CACHUCHO, R., and VAN DIJK, J.A.G.M., 2021. Acceptance of Technologies for Aging in Place: A Conceptual Model. Journal of Medical Internet Research, vol. 23, no. 3, e22613.

JASCHINSKI, C., and BEN ALLOUCH, S., 2019. Listening to the ones who care: Exploring the perceptions of informal caregivers towards ambient assisted living applications. Journal of Ambient Intelligence and Humanized Computing, vol. 10, no. 2, pp. 761-778.

KHOSRAVI, P., REZVANI, A., and WIEWIORA, A., 2016. The impact of technology on older adults' social isolation. Computers in Human Behavior, vol. 63, pp. 594-603.

KRÖGER, T., MATHEW PUTHENPARAMBIL, J., and VAN AERSCHOT, L., 2019. Care poverty: Unmet care needs in a Nordic welfare state. International Journal of Care and Caring, vol. 3, no. 4, pp. 485-500.

LILHOLT, P. H., HÆSUM, L. K. E., EHLERS, L. H., and HEJLESEN, O. K., 2016. Specific technological communication skills and functional health literacy have no influence on self-reported benefits from enrollment in the TeleCare North trial. International Journal of Medical Informatics, vol. 91, pp. 6o-66. 
MAHONEY, D., 2011. An Evidence-Based Adoption of Technology Model for Remote Monitoring of Elders' Daily Activities. Ageing International, vol. 36, no. 1, pp. 66-81.

NEYER, F. -J., FELBER, J., and GEBHARDT, C., 2012. Development and validation of a brief measure of technology commitment. Diagnostica, vol. 58, no. 2, pp. 87-99.

OLSSON, A., ENGSTRÖM, M., SKOVDAHL, K., and LAMPIC, C., 2012. My, your and our needs for safety and security: Relatives' reflections on using information and communication technology in dementia care. Scandinavian Journal of Caring Sciences, vol. 26, no. 1, pp. 104-112.

SIEGEL, C., and DORNER, T.-E., 2017. Review article: Information technologies for active and assisted living-Influences to the quality of life of an ageing society. International Journal of Medical Informatics, vol. 10o, pp. $32-45$.

SOCIAL PROTECTION COMMITTEE (SPC), and EUROPEAN COMMISSION (DG EMPL), 2021. 2021 Long-Term Care Report-Trends, challenges and opportunities in an ageing society. Volume I. Luxembourg: Publications Office of the European Union [online]. [viewed 15 June 2021]. Available from: https://ec.europa.eu/social/main.jsp?catId=738andlangId=enandpubId $=8396$

SPASOVA, S., BAETEN, R., COSTER, S., GHAILANI, D., PENA-CASAS, R., and VANHERCKE, B., 2018. Challenges in long-term care in Europe-A study of national policies. Brussels: European Commission, Directorate-General for Employment, Social Affairs and Inclusion [online]. [viewed 15 March 2019]. Available from: https://ec.europa.eu/social/BlobServlet?docId $=20225$ andlangId $=$ en

STEILS, N., WOOLHAM, J., FISK, M., PORTEUS, J., and FORSYTH, K., 2021. Carers' involvement in telecare provision by local councils for older people in England: Perspectives of council telecare managers and stakeholders. Ageing and Society, vol. 41, no. 2, pp. 456-475.

TUR-SINAI, A., TETI, A., ROMMEL, A., HLEBEC, V., and LAMURA, G., 2020. How Many Older Informal Caregivers Are There in Europe? Comparison of Estimates of Their Prevalence from Three European Surveys. International Journal of Environmental Research and Public Health, vol. 17, no. 24, 9531.

VERLOO, H., KAMPEL, T., VIDAL, N., and PEREIRA, F., 2020. Perceptions About Technologies That Help Community-Dwelling Older Adults Remain at Home: Qualitative Study. Journal of Medical Internet Research, vol. 22, no. 6. e17930.

WILES, J. L., LEIBING, A., GUBERMAN, N., REEVE, J., and ALLEN, R. E. S., 2012. The Meaning of "Aging in Place" to Older People. The Gerontologist, vol. 52, no. 3, pp. 357-366. 
WILliAMSON, B., APLIN, T., DE JONGE, D., and GOYNE, M., 2017. Tracking down a solution: Exploring the acceptability and value of wearable GPS devices for older persons, individuals with a disability and their support persons. Disability and Rehabilitation. Assistive Technology, vol. 12, no. 8 , pp. $822-831$.

ZIGANTE, V., 2018. Informal Care in Europe: Exploring Formalisation, Availability and Quality. Brussels: Publications Office.

ZIGANTE, V., 2021. The Role of New Technologies in Modernising Long-term Care Systems - A scoping review. Luxembourg: Publications Office of the European Union [online]. [viewed 30 April 2020]. Available from: https:// ec.europa.eu/social/BlobServlet?docId=23362 andlangId $=\mathrm{mt}$ 